\title{
Epidemiological and clinical characteristics of scorpionism in Shiraz (2012-2016); development of a clinical severity grading for Iranian scorpion envenomation
}

\author{
Hossein Sanaei-Zadeh ${ }^{1 *}$, Sayed Mahdi Marashi ${ }^{1}$, Rouhullah Dehghani ${ }^{2}$ \\ Received: 23 Nov 2016 \\ Published: 17 May 2017
}

\begin{abstract}
Background: Scorpionism is a public health problem in some provinces in Iran. The present study aimed to assess the clinical manifestations of scorpion envenomation in Shiraz and determine a clinical severity grading for Iranian scorpion envenomation in order to suggest a treatment guideline for emergency physicians.

Methods: In this analytic retrospective study, all medical charts of patients with scorpion sting admitted in the adult medical toxicology center in Shiraz during July 2012 to July 2016 were assessed. Data regarding the patient's age, gender, sting site, month of envenomation, time of sting, clinical manifestations, vital signs, presence of blood or hemoglobin in urine analysis, duration of admission, color of scorpion, received treatments, and administration of scorpion antivenin were recorded.

Results: The scorpions in Shiraz and its suburban area were classified into two groups: yellow scorpions (Mesobuthus eupeus, Mesobuthus caucasicus, and Compsobuthus matthiesseni) and Hottentotta scorpions (Hottentotta jayakari and Hottentotta zagrosensis). A total of 126 cases of scorpion stings were assessed. About $59 \%(\mathrm{n}=74)$ were males. The patients aged 8-63 years (mean age, 33.8 \pm 11.5 years). About $38.4 \%(n=48)$ of the stings occurred during summer. More than $40 \%$ of patients $(n=51)$ referred to the emergency department (ED) at night. Localized pain was the most frequent presenting complaint (76.2\%). The most frequent general symptom was nausea $(6.3 \%)$. The most prevalent envenomation site was the lower extremities followed by upper extremities $(43.5 \%$ and $41.9 \%$, respectively). Based on the clinical severity grading for Iranian scorpion envenomation, 65,43 , and 18 patients $(51.6 \%, 34.1 \%$, and $14.3 \%$ ) were classified in the grades I, II, and III, respectively. Eighty-one (73\%) patients stayed in the ED from 1 to 6 hours, and 30 $(27 \%)$ patients stayed for $>6$ hours for observation. Severe localized pain was more prevalent in stings with Hottentotta scorpions than yellow scorpions $(\mathrm{P}=0.01)$. The season of envenomation with Hottentotta scorpions was summer in all cases, but envenomation with yellow scorpions was seen throughout the year. All patients received symptomatic treatment, and five were given scorpion antivenin. No death was reported.
\end{abstract}

Conclusion: Hottentotta jayakari is recommended to be listed among the medically important scorpions in Iran. Moreover, scorpion-stung patients in geographical regions where Hemiscorpius lepturus and Androctonus crassicauda are not prevalent may be treated in outpatient departments. The presented grading system can be used for treating patients with scorpion envenomation.

Keywords: Scorpions, Scorpion Stings, Iran, Epidemiology, Clinical Manifestations, Clinical Severity Grading

Copyright $₫$ Iran University of Medical Sciences

Cite this article as: Sanaei-Zadeh H, Marashi SM, Dehghani R. Epidemiological and clinical characteristics of scorpionism in Shiraz (2012-2016); development of a clinical severity grading for Iranian scorpion envenomation. Med J Islam Repub Iran. 2017 (17 May); $31: 27$. https://doi.org/10.18869/mjiri.31.27

\section{Introduction}

Scorpions have been living on earth for more than 400 years (1). So far, about 2000 scorpion species have been identified, 25 of which have medical significance $(2,3)$. Their venom differs among different species and consists

Corresponding author: Dr Hossein Sanaei-Zadeh, sanaeizadeh@sums.ac.ir

1. Emergency Room, Division of Medical Toxicology, Hazrat Ali-Asghar, Hospital, Shiraz University of Medical Sciences, Shiraz, Iran.

2. Social Determinants of Health Research Center and, Department of Environmental Health, College of Health, Kashan University of Medical Sciences, Kashan, Iran. of proteins and other substances (4). Annually, about half a million people are stung by scorpions worldwide with a mortality rate of 3250 individuals $(5,6)$. Scorpion stings are one of the most important environmental health haz-

\section{$\uparrow$ What is "already known" in this topic:}

In Iran, about 51 scorpion species have been reported, among which 11 species are medically important. There is still no grading system for the severity of Iranian scorpion envenomation and no clear treatment guidelines for emergency physicians.

$\rightarrow$ What this article adds:

Hottentotta jayakari species should be regarded among the medically important scorpions of Iran. For the first time, a clinical severity grading for Iranian scorpion envenomation was presented. 
ards in Iran. Although, more than fifty thousands of scorpion stings are reported annually, around $75 \%$ of fatal cases are reported from Khuzestan, Sistan-Baluchestan, Kerman and Hormozgan provinces (7-9).

The Hemiscorpius lepturus and Androctonus crassicau$d a$ species are responsible for most fatal envenomation cases in Iran (9-12). The clinical manifestations of scorpion envenomation can be a challenge for emergency physicians since they are diverse, ranging from mild burning sensations at the sting site to critical fatal conditions (13).

In Iran, about 51 scorpion species have been reported, among which 11 species are medically important $(9,14)$. The characteristics of these medically important scorpions and their clinical envenomation manifestations are provided in Table 1 (9-12, 14-33). Previous studies have reported the clinical manifestations of scorpion stings in provinces with high rates of scorpionism $(7,31-89)$. However, there is still no grading system for the severity of Iranian scorpion envenomation and no clear treatment guidelines for emergency physicians. Moreover, there is only one study on scorpion envenomation in Shiraz, reporting patients with scorpion envenomation to a tertiary hospital from southern Iran (90).

The current study aimed to assess the clinical manifestations of scorpion envenomation in Shiraz and to determine a grading system regarding its severity via reviewing its clinical manifestations in Iran to provide a treatment guideline for emergency physicians.

\section{Methods}

Shiraz (N $\left.52^{\circ} 32^{\prime} \mathrm{E}^{\prime} 37^{\circ} 29\right)$, the capital of Fars province, is the sixth most populated city in Iran situated in the southwest of the country and has a mild climate. Its population was about $1,500,000$ in the 2011 census (91). In July 2012, the Division of Medical Toxicology was established in the Emergency Room of Hazrat Ali-Asghar (p) Hospital, as the only adult medical toxicology center in Shiraz. Until then, there was no information on the most common scorpion species and clinical manifestations of their stings in this geographical region. Hence, scorpions, brought by afflicted patients, were kept in alcohol 70\% and sent to the laboratory of the Department of Environmental Health of Kashan University of Medical Sciences. These scorpions were identified based on the diagnostic keys for Iranian scorpions (92-94). In this analytic retrospective study, all medical charts of patients with scorpion sting admitted during July 2012 to July 2016 were assessed. Data regarding the patient's age, gender, site of sting, month of envenomation, time of sting, clinical manifestations, vital signs, presence of blood or hemoglobin in urine analysis (U/A), duration of admission, color of scorpion, received treatments, and administration of scorpion antivenin were extracted and recorded. If the color of the scorpion was not in the records, the patients or their families were called. Stings occurring in regions other than Shiraz and its suburban area were excluded from the study. Also, patients with underlying cardiovascular and renal diseases and those who were receiving anticoagulants were excluded. Scorpions of the genus Hottentotta differ in terms of size and color with other solid yellow scorpions (94). In fact, stings with these great size scorpions with different coloration are more intimidating. Moreover, as they belong to a relatively large species of scorpions, severe clinical symptoms would be expected on their stings, depends upon the large amount of the venom injected. Therefore, the scorpion stings were divided into stings from Hottentotta and yellow scorpions. A classification was developed on the basis of the reported clinical manifestations of scorpion-stung patients from Iran (9-12, 14-33) and was utilized to grade the clinical severity of scorpion envenomation for the stung patients.

Data were analyzed by using SPSS software, version 22.0 using Mann-Whitney U, Fisher's exact, Pearson's Chi-square, and student's t-test. A p-value of less than 0.05 was considered statistically significant.

\section{Ethical considerations}

The study was approved on May 23, 2016 by the Committee of Ethics in Research, Medical School, Shiraz University of Medical Sciences and registered as IR.SUMS. MED.REC.1395.S98.

\section{Results}

A total of 28 scorpion samples of the patients were collected. After identification at the laboratory, the scorpions in Shiraz and its suburban area were classified into two groups: yellow scorpions (Mesobuthus eupeus $(\mathrm{n}=10)$, Mesobuthus caucasicus ( $\mathrm{n}=9)$, and Compsobuthus matthiesseni $(\mathrm{n}=2)$ ) and Hottentotta scorpions (Hottentotta jayakari $(\mathrm{n}=6)$ and Hottentotta zagrosensis (1)) with respective prevalence (Fig. 1 to 5).

During the study period (July 2012 to July 2016), the total number of scorpion sting cases reviewed was 126 . The gender distribution showed 59\% $(\mathrm{n}=74)$ males and $41 \%$ $(\mathrm{n}=52)$ females. The patients aged 8 to 63 years (mean age of $33.8 \pm 11.5$ years). About $38.4 \%$ of the stings occurred during summer, most of which occurring in August. More than $40 \%$ of patients $(n=51)$ referred to the emergency department (ED) at night between $00.00 \mathrm{am}$ to $06.00 \mathrm{am}$.

The most prevalent site of envenomation was the lower extremities (53 cases, 43.1\%), followed by upper extremi-

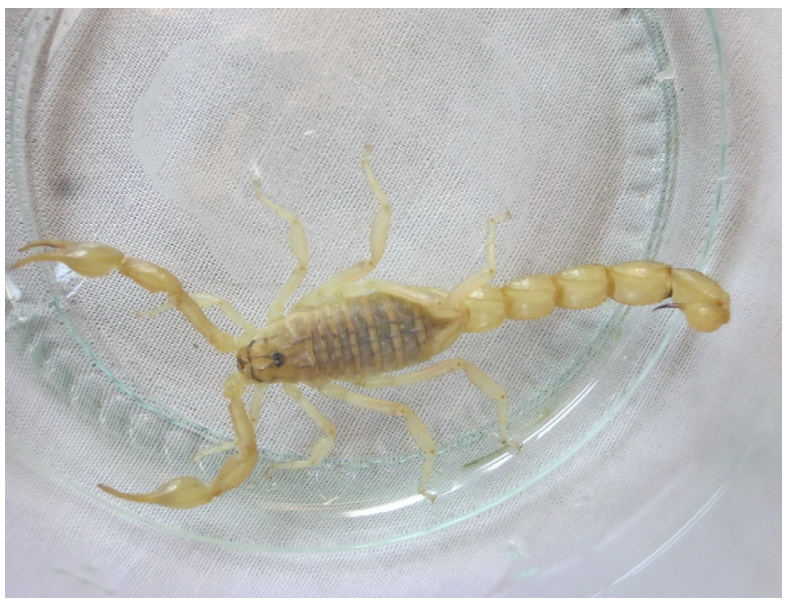

Fig. 1. Mesobuthus eupeus (original picture) 


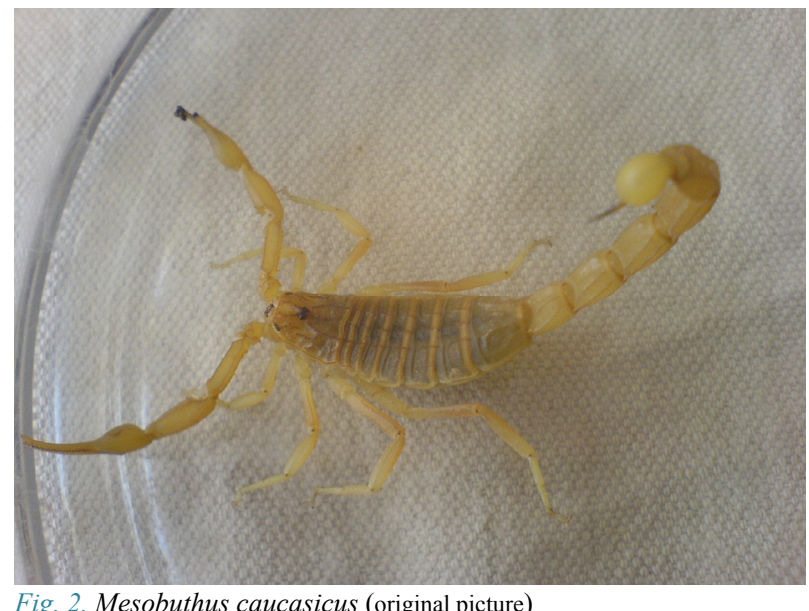

Mesobuthus caucasicus (original picture)

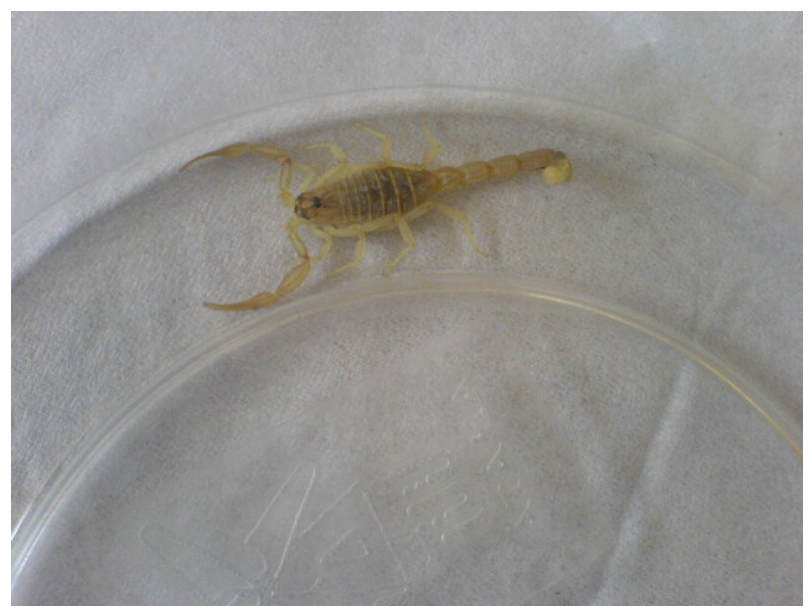

Fig. 3. Compsobuthus matthiesseni (original picture)

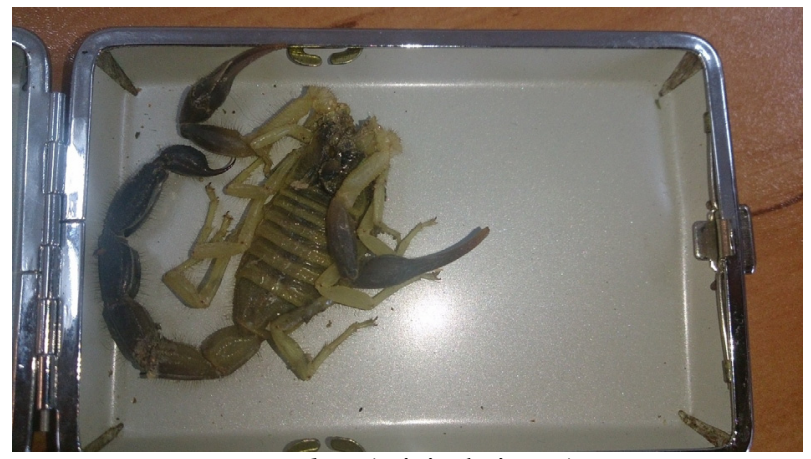

Fig. 4. Hottentotta jayakari (original picture)

ties (52 cases, 42.3\%), trunk (10 cases, 8.1\%), and head and neck (9 cases, 7.3\%). Also, there was one case of simultaneous hand and foot sting and one case of simultaneous trunk and hand sting.

The vast majority of the patients $(95 ; 75.4 \%)$ had only localized manifestations including local mild to severe pain $(\mathrm{n}=81 ; 64.3 \%)$, burning sensation $(\mathrm{n}=39 ; 30.1 \%)$, mild erythema $(n=32 ; 25.4 \%)$, mild swelling $(n=12$; $9.5 \%)$, pruritus $(n=8 ; 6.3 \%)$, and tenderness $(n=2 ; 1.6 \%)$. The general symptoms included nausea $(n=8 ; 6.3 \%)$, vertigo $(n=4 ; 3.2 \%)$, fatigue $(n=3 ; 2.4 \%)$, dyspnea $(n=3$; $2.4 \%)$, sweating $(n=1 ; 0.8 \%)$, shivering $(n=1 ; 0.8 \%)$, chest pain $(\mathrm{n}=1 ; 0.8 \%)$, flushing $(\mathrm{n}=1 ; 0.8 \%)$, and epigastric

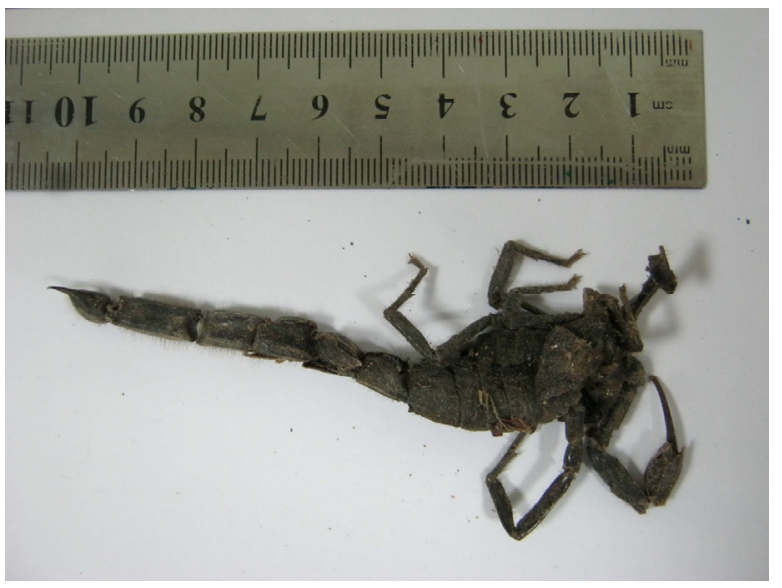

Fig. 5. Hottentotta zagrosensis, previously named as Buthotus schach (dead specimen; original picture)

pain $(\mathrm{n}=1 ; 0.8 \%)$ with no systemic involvement. Also, 80 $(63.5 \%)$ and $15(11.9 \%)$ cases were diagnosed as yellow and Hottentotta scorpion stings, respectively. In 31 $(24.6 \%)$ of the stung patients, the color of the scorpions was not determined.

The clinical manifestations of scorpion stings with respect to the scorpions' color and size are given in Table 3 . Severe localized pain was more prevalent in stings with Hottentotta than yellow scorpions ( $\mathrm{p}=0.01$, Fisher's exact test). In addition, the patients stung with Hottentotta scorpions needed more antivenin $(\mathrm{p}=0.002$, Fisher's exact test). There were no significant statistical differences between these two groups regarding other clinical manifestations, vital signs, clinical severity grading, or length of ED stay.

The classification shown in Table 2 was utilized to grade the clinical severity of scorpion envenomation for all cases. According to the present clinical severity grading classification, 65,43 , and 18 of the patients $(51.6 \%$, $34.1 \%$, and $14.3 \%$ ) were classified in the grades I, II, and III, respectively.

In all cases, the season of envenomation with Hottentotta scorpions was summer, but envenomation with yellow scorpions was reported throughout the year.

The length of ED stay was classified into two groups: $81(73 \%)$ patients (of 111 patients with valid data) stayed from 1 to 6 hours, and $30(27 \%)$ patients stayed for $>6$ hours for observation. Thirty-two patients $(25 \%)$ discharged themselves against medical advice.

In general, all patients received intravenous hydrocortisone and intramuscular antihistamines injections. Some of the patients received local injection of lidocaine, analgesics, meperidine (pethidine), and/or local application of ice pack to the sting site for pain relief, and five (4\%) patients received scorpion antivenin. Scorpion antivenin was given to the patients with grade III clinical severity grading classification.

In 12 cases ( 2 males and 10 females) of envenomation with yellow scorpions, microscopic hematuria was reported in the U/A (positive hemoglobin/blood in urine dipstick together with microscopic red blood cells). All patients were discharged in good condition. There was no death. 
Table 1. Medically important scorpions of Iran and clinical manifestations of their stings (9-12, 14-33)

\begin{tabular}{|c|c|c|c|}
\hline Scorpion species & $\begin{array}{l}\text { Apparent } \\
\text { color }\end{array}$ & Size & Clinical manifestations of the sting \\
\hline Hemiscorpius lepturus & Yellow & $\begin{array}{l}\text { Male: } 5 \mathrm{~cm} \\
\text { Female: } \\
7.5-8 \mathrm{~cm}\end{array}$ & $\begin{array}{l}\text { Local: minor to mild local pain, local pruritus, erythema, inflammation, ecchymosis, } \\
\text { severe swelling, blisters, cellulitis, extensive skin necrosis at the site of the sting. } \\
\text { Systemic: drowsiness, fatigue, irritability, restlessness, hyperthermia, pallor, sweat- } \\
\text { ing, hypotension, cool extremities, tachycardia, muscle spasms, convulsion. Labora- } \\
\text { tory: leukocytosis, hematuria, hemoglobinuria, myoglobinuria (rhabdomyolysis), } \\
\text { proteinuria, hemolytic anemia, elevated liver enzymes, increased PT and PTT, DIC, } \\
\text { HUS, acute renal failure }\end{array}$ \\
\hline Androctonus crassicauda & Black & $11-12 \mathrm{~cm}$ & $\begin{array}{l}\text { Local: local burning pain at the site of the sting. Systemic: due to the increased } \\
\text { release of acetylcholine and catecholamines: drowsiness, irritability, restlessness, } \\
\text { decreased level of the consciousness, miosis, tachypnea, excessive sweating, saliva- } \\
\text { tion, diarrhea, nausea, vomiting, urination, severe abdominal cramps, numbness of } \\
\text { limbs, tachycardia, filiform pulse, hypotension, hypothermia, cool extremities, de- } \\
\text { creased tendon reflexes, cyanosis, excessive thirst, ECG changes, acute pulmonary } \\
\text { edema, melena, bloody vomiting. Laboratory: leukocytosis, granulocytosis, lym- } \\
\text { phopenia, glucosuria, hemoglobinuria, proteinuria }\end{array}$ \\
\hline $\begin{array}{l}\text { Buthotus (Hottentotta) } \\
\text { saulcyi }\end{array}$ & Yellow & $12-13 \mathrm{~cm}$ & Severe pain at the site of the sting, other clinical manifestations (are questionable) \\
\hline Odontobuthus doriae & Yellow & $7-8.5 \mathrm{~cm}$ & $\begin{array}{l}\text { Prolonged severe pain at the site of sting with radiation to its periphery, severe mus- } \\
\text { cle contractions in the affected extremity (twitching), irritability, restlessness, tachy- } \\
\text { cardia, tachypnea, dyspnea, unilateral acute pulmonary edema }\end{array}$ \\
\hline Mesobuthus eupeus & Yellow & $5-6 \mathrm{~cm}$ & $\begin{array}{l}\text { Local: moderate to severe pain or burning sensation at the site of sting, Systemic: } \\
\text { thirst, dry mouth, headache, nausea, irritability, restlessness, tachycardia, tachypnea, } \\
\text { transient ophthalmoplegia }\end{array}$ \\
\hline Orthochirus scrobiculosus & Black & $2.5-4 \mathrm{~cm}$ & Severe pain and prolonged itching at the site of sting, one death has been reported \\
\hline Apistobuthus pterygocercus & Yellow & $7-8 \mathrm{~cm}$ & $\begin{array}{l}\text { Anxiety, miosis, rhinorrhea, dacryorrhea, hypersalivation, tachypnea, shortness of } \\
\text { breath, wheezing, gastric distention, and abdominal bulge }\end{array}$ \\
\hline $\begin{array}{l}\text { Mesobuthus (Olivierus) } \\
\text { caucasicus }\end{array}$ & Yellow & $6-6.5 \mathrm{~cm}$ & Similar to the Mesobuthus eupeus \\
\hline Hemiscorpius acanthocercus & Yellow & $\begin{array}{l}\text { Male: } 5 \mathrm{~cm} \\
\text { Female: } \\
7.5-8 \mathrm{~cm}\end{array}$ & Similar to the Hemiscorpius lepturus, one death has been reported \\
\hline $\begin{array}{l}\text { Hottentotta zagrosensis } \\
\text { (previously named as } \\
\text { Buthotus schach) }\end{array}$ & Black & $13 \mathrm{~cm}$ & Not reported \\
\hline Compsobuthus matthiesseni & Yellow & $4-5 \mathrm{~cm}$ & Hematuria (is questionable) \\
\hline
\end{tabular}

\section{Discussion}

Most fatal scorpion envenomations in Iran are related to H. lepturus and A. crassicauda species (9-12). This study found no envenomation case with these species in Shiraz and its suburbs. Azizi et al. in 1998 studied scorpions in the villages around Shiraz and reported that M. eupeus, A. crassicauda, and $H$. lepturus fauna were respectively more prevalent (95). Moreover, other researchers have recently reported M. eupeus, A. crassicauda, and Orthochirus scrobiculosus fauna in villages around Shiraz (96). The reason for the different fauna reported in these two studies and the species of the scorpion samples in the current study is unknown, but it might be attributed to the reduced population of some species due to the modernization of rural areas around Shiraz.

The clinical manifestations of stings by medically important scorpions in Iran have been previously reported except for $H$. schach and $C$. matthiesseni. In addition, the systemic clinical manifestations of envenomation by $M$. eupeus and $H$. saulcyi are questionable. Regarding the clinical manifestations of sting by M. eupeus, Radmanesh believes that the systemic manifestations of sting by this scorpion are caused by the fear of being stung, and this species does not cause severe clinical manifestations $(9$, 15). However, transient ophthalmoplegia following envenomation by $M$. eupeus has been reported from Iran
(31).

The only study reporting the clinical manifestations of envenomation with $M$. eupeus in other countries is a retrospective study by Ozkan and Kat on 152 patients in the Sanliurfa region of Turkey (97). The most prevalent local clinical manifestations of $M$. eupeus were swelling, hyperemia, pain, burning, itching, and numbness, and systemic clinical manifestations were reported in $9 \%$ of the cases. Systemic manifestations consisted of dry mouth, thirst, sweating, hypotension, nausea, hypertension, difficulty in breathing, tachycardia, an increase of bronchial secretion, and cyanosis with respective prevalence. However, laboratory identification of the species was not done, and the species were identified according to the color of the scorpion self-reported by the patients (97). Therefore, other species might have been responsible for the socalled local and systemic manifestations.

It has been reported that the clinical manifestations of envenomation with $M$. caucasicus is similar to those of $M$. eupeus $(9,72,73)$. In the present study, the most common general symptoms caused by envenomation with yellow scorpions were as follows: nausea $(\mathrm{n}=8 ; 6.3 \%)$, vertigo $(\mathrm{n}=4 ; 3.2 \%)$, fatigue $(\mathrm{n}=3 ; 2.4 \%)$, dyspnea $(\mathrm{n}=3 ; 2.4 \%)$, sweating $(\mathrm{n}=1 ; 0.8 \%)$, shivering $(\mathrm{n}=1 ; 0.8 \%)$, chest pain $(\mathrm{n}=1 ; 0.8 \%)$, flushing $(\mathrm{n}=1 ; 0.8 \%)$, and epigastric pain $(\mathrm{n}=1 ; 0.8 \%)$. 
Table 2. Grades of scorpion sting severity on the basis of the reported clinical manifestations of scorpion-stung patients from Iran (9-12, 14-33)

\begin{tabular}{|c|c|}
\hline Grade & Clinical picture \\
\hline$I$ & - $\quad$ Mild localized symptoms \\
\hline II & $\begin{array}{l}\text { - Moderate to severe local pain } \\
\text { - } \quad \text { or microscopic hematuria }\end{array}$ \\
\hline$I I I$ & $\begin{array}{l}\text { - } \quad \text { Prolonged severe pain at the site of sting with radiation to its periphery (not responding to treatment), } \\
\text { - } \quad \text { and/or prolonged local severe itching (not responding to treatment), } \\
\text { - } \quad \text { ond microscopic hemoglobinuria (in endemic regions for H. lepturus or H. acanthocercus) }\end{array}$ \\
\hline$I V$ & $\begin{array}{l}\text { - Severe cutaneous manifestations (in endemic regions for H. lepturus or H. acanthocercus) } \\
\text { - } \quad \text { and/or abnormal vital signs } \\
\text { - } \quad \text { and/or muscle spasm, twitching } \\
\text { - } \quad \text { and/or dark red urine (gross hemoglobinuria) } \\
\text { - } \quad \text { and/or hemolysis, and/or DIC, and/or HUS }\end{array}$ \\
\hline
\end{tabular}

However, in contrast to Ozkan and Kat's study (97), the vital signs were in the normal limit upon presentation and during admission. Most patients had localized manifestations, and no systemic involvement was found. However, in $12(10 \%)$ cases of envenomation with yellow scorpions, microscopic hematuria was reported. Menstruation might have been responsible for hematuria since 10 patients were female, and this was not recorded in the hospital records. Moreover, hematuria was reported in evenomations by $C$. matthiesseni species $(9,92)$.

This is the first report regarding scorpion envenomation in adults, form Shiraz and its suburbs, Iran. The only related study on scorpionism in Shiraz was done by Sagheb et al. who had assessed referred patients with scorpion envenomation to a tertiary hospital from southern Iran (90). They found that $6 \%$ of the patients had systemic clinical manifestations, among which acute renal failure and disseminated intravascular coagulation were the most common. H. lepturus was responsible for these two systemic manifestations. The current study is not comparable with this study since all referrals including children from southern Iran, and other provinces were involved.

It is for the first time in Iran that envenomations by $H$. jayakari species are reported. Since this species has been found in other parts of Iran $(11,83,94,98-101)$, it may be listed among the medically important scorpions of Iran. It is hunted in Sistan-Baluchestan (83), Hormozgan (94, 100), and Fars (11) provinces and Qeshm (101), Kish (99), Hengam, and Tonb-e Bozorg (98) islands of the Persian Gulf.

The clinical manifestations of $H$. zagrosensis sting (previously named as Buthotus schach) $(9,11,18,40,44,92$, 93, 102-104) not previously reported from Iran. A percentage of stings by Hottentotta scorpions were caused by this species. Hottentotta zagrosensis is hunted in Fars, Khuzestan, West Azarbaijan (11, 40, 44, 96, 105-107),

Table 3. Comparison of clinical manifestations of scorpion stings with respect to the scorpions' color and size

\begin{tabular}{|c|c|c|c|}
\hline Clinical manifestations & $\begin{array}{c}\text { Yellow scorpions } \\
(\text { no }=80)\end{array}$ & $\begin{array}{l}\text { Hottentotta scorpions } \\
(\text { no }=15)\end{array}$ & $P$ value \\
\hline Local pain & $37(46.3 \%)$ & $4(26.7 \%)$ & 0.130 \\
\hline Burning sensation & $34(42.5 \%)$ & $3(20 \%)$ & 0.085 \\
\hline Mild erythema & $26(32.5 \%)$ & $4(26.7 \%)$ & 0.454 \\
\hline Severe local pain (with or without radiation to its periphery) & $20(25 \%)$ & $9(60 \%)$ & 0.010 \\
\hline Mild swelling & $10(12.5 \%)$ & $2(13.3 \%)$ & 0.602 \\
\hline Local pruritus & $6(7.5 \%)$ & $1(6.7 \%)$ & 0.695 \\
\hline Local paresthesia & $1(1.3 \%)$ & $0(0 \%)$ & 0.842 \\
\hline Nausea & $5(6.3 \%)$ & $0(0 \%)$ & 0.415 \\
\hline Fatigue & $2(2.5 \%)$ & $1(6.7 \%)$ & 0.406 \\
\hline Dyspnea & $1(1.3 \%)$ & $0(0 \%)$ & 0.842 \\
\hline Vertigo & $2(2.5 \%)$ & $1(6.7 \%)$ & 0.406 \\
\hline Sweating & $1(1.3 \%)$ & $0(0)$ & 0.842 \\
\hline Shivering & $0(0 \%)$ & $1(6.7 \%)$ & 0.158 \\
\hline Chest pain & $1(1.3 \%)$ & $0(0 \%)$ & 0.842 \\
\hline Flushing & $1(1.3 \%)$ & $0(0 \%)$ & 0.842 \\
\hline Epigastric pain & $1(1.3 \%)$ & $0(0 \%)$ & 0.842 \\
\hline Muscle spasm & $1(1.3 \%)$ & $0(0 \%)$ & 0.842 \\
\hline Pulse rate/min $($ mean \pm SD) & $82.50 \pm 12.81$ & $86.57 \pm 10.88$ & 0.828 \\
\hline Respiratory rate/min (mean $\pm \mathrm{SD})$ & $18.06 \pm 2.20$ & $17.42 \pm 2.06$ & 0.792 \\
\hline Systolic blood pressure $(\mathrm{mmHg})($ mean $\pm \mathrm{SD})$ & $117.01 \pm 16.02$ & $127.21 \pm 16.42$ & 0.791 \\
\hline Diastolic blood pressure $(\mathrm{mmHg})($ mean $\pm \mathrm{SD})$ & $76.00 \pm 14.60$ & $80.42 \pm 10.72$ & 0.297 \\
\hline Microscopic hematuria & $9(11.3 \%)$ & $0(0 \%)$ & 0.197 \\
\hline Severity grade I & $42(52.5 \%)$ & $6(40 \%)$ & 0.272 \\
\hline Severity grade II & $27(33.8 \%)$ & $8(53.3 \%)$ & 0.126 \\
\hline Severity grade III & $11(13.8 \%)$ & $1(6.7 \%)$ & 0.398 \\
\hline Length of ED stay $(<6 \mathrm{~h})$ & $51(71.8 \%)$ & $9(60 \%)$ & 0.270 \\
\hline Scorpion antivenin administrated & $1(1.3 \%)$ & $4(26.7 \%)$ & 0.002 \\
\hline
\end{tabular}

SD: standard deviation; ED: emergency department 
Lorestan (108), Qazvin (109), Chaharmahal-Bakhtiari $(110,111)$, and Kohgiluyeh-Boyer-Ahmad (112) provinces in Iran.

It was found that scorpion envenomations are more common in summer and at night, in line with other studies on scorpion envenomation $(7,28,40-52,65,66,69,70$, 74-83, 87-89). Moreover, envenomations with Hottentotta scorpions were only reported in summer, and the pain was more prevalent in patients stung by Hottentotta scorpions compared to yellow scorpions. This could be attributed to the bigger size of telson of Hottentotta scorpions. According to the present study, despite the large size, the severity of clinical manifestations of Hottentotta species envenomation is similar to other studied yellow scorpions, except for severe localized pain.

About $70 \%$ of the patients were admitted for 1-6 hours, and some insisted on being discharged despite medical advice to stay longer, representing their good general condition. Since the severity of most envenomations was grade I and II, it seems that scorpion stung patients in Shiraz and other geographical regions in Iran, where H. lepturus and $A$. crassicauda stings are not prevalent, can be treated in the outpatient departments, not highly crowded emergency departments.

In this study, a grading system for the severity of scorpion envenomation was presented for the first time based on the clinical manifestations of scorpion stings in Iran. This grading could be used for treating patients. So, those with grades I and II could be treated symptomatically, and scorpion antivenin could be used for patients with grades III and VI, similar to the protocol used in managing the patients. However, no patient with grade VI severity was reported.

In Iran, Razi Vaccine and Serum Research Institute is responsible for producing anti-scorpion serum. This polyvalent scorpion antivenin is prepared from the purified plasma of healthy horses immunized with venoms of the six medically important scorpion species in Iran including $O$. doriae, M. eupeus, A. crassicauda, B. saulcyi, B. schach, and H. lepturus (113). As previously mentioned, $H$. lepturus and $A$. crassicauda are among the most dangerous scorpion species in Iran, and their stings can be fatal (9-12). Although there is no definite treatment protocol for envenomation by these species, Valavi (114) suggests that the best treatment for such stings, in cases presenting no systemic or general symptoms, is slow intravenous administration of one ampule of scorpion antivenin after cutaneous testing. Then, the decision to administer more antivenin should be made according to repeated urine tests (appearance of hemoglobinuria) in cases of $H$. lepturus envenomation and the manifestation of other signs and symptoms of $A$. crassicauda sting. However, in patients with hemoglobinuria or systemic or general symptoms, 3-6 intravenous antivenins should be slowly prescribed after cutaneous testing depending on the severity of symptoms. If the species of scorpion is not known, patients should be treated considering the progression of signs and symptoms, appearance of hemoglobinuria, or other systemic manifestations (114).

In this study, only the adult patients admitted to medi- cal toxicology center in Shiraz were assessed. Patients treated in outpatient departments or not referring to hospitals for treatment due to the mild symptoms were not included. In other words, scorpion envenomation is definitely more prevalent in Shiraz compared with the current statistics. Also, the results cannot be generalized to children since only the adults were included. Furthermore, like any other retrospective studies, they were other limitations in our study. Some of the data were missing in some of the patients' chart. Also, some of the charts were missing and thus we could not include them in the study.

\section{Conclusion}

It is recommended to list $H$. jayakari among the medically important scorpions of Iran. Moreover, it seems that patients stung by scorpions in geographical regions in which $H$. lepturus and $A$. crassicauda stings are not prevalent could be treated in outpatient departments. The presented grading system can be used for treating patients with scorpion envenomation. The stung patients with grades I and II envenomation could be treated symptomatically, and scorpion antivenin could be used only for patients with grades III and VI.

\section{Acknowledgment}

The authors would like to thank the nurses of the Emergency Room, the Division of Medical Toxicology, Hazrat Ali-Asghar (p) Hospital, Shiraz, Iran for their assistance in collecting the scorpion samples of the patients.

Conflict of Interests: The authors of this article declare that they have no competing interests.

\section{References}

1. Ozkan O, Adiguzel S, Kar S, Kurt M, Yakistiran S, Cesaretli Y, Orman M, Karaer Z. Effects of Androctonus crassicauda (Olivier, 1807) (Scorpiones: Buthidae) venom on rats: correlation among acetyl cholinesterase activities and electrolytes levels. J Venom Anim Toxins incl Trop Dis. 2007;13(1): 69-81

2. van der Meijden A, Lobo Coelho P, Sousa P, Herrel A. Choose your weapon: defensive behavior is associated with morphology and performance in scorpions. PLoS One. 2013;8: e78955.

3. Mansour N. Waiting time and characteristics of taking in charge scorpion priced persons in Sidi-Bouzid region Institute Pasteur de Tunis, Tunis, Tunisia. Arch Inst Pasteur Tunis. 2001;78: 25-31.

4. Quintero-Hernández V, Jiménez-Vargas JM, Gurrola GB, Valdivia $\mathrm{HH}$, Possani LD. Scorpion venom components that affect ionchannels function. Toxicon. 2013;76: 328-42.

5. Bosnak M, Ece A, Yolbas I, Bosnak V, Kaplan M, Gurkan F. Scorpion sting envenomation in children in southeast Turkey. Wilderness Environ Med. 2009;20(2): 118-24.

6. Bawaskar HS, Bawaskar PH. Scorpion sting: update. J Assoc Physicians India. 2012;60(1): 46-55.

7. Kassiri H, Kassiri A, Sharififard M, Shojaee S, Lotfi M, Kasiri E. Scorpion envenomation study in Behbahan County, Southwest Iran. J Coast Life Med. 2014;2(5): 416-20.

8- Sedaghat MM, Salehi Moghadam AR, Dehghani R. Mapping the distribution of some important scorpions collected in the past five decades in Iran. J Army Univ Med Sci. 2011;9(4): 285-96 [in Persian].

9. Dehghani R, Fathi B. Scorpion sting in Iran: a review. Toxicon. 2012;60(5): 919-33.

10. Dehghani R, Valaie N. The review of status of scorpion sting in Iran and problems from its. FEYZ, J Kashan Univ of Med Sci. 2005;9(33): 73-92 [in Persian].

11. Jalali A, Rahim F. Epidemiological Review of Scorpion Enven- 
omation in Iran. Iran J Pharm Res. 2014;13(3): 743-56.

12- Radmanesh M. Surveying scorpion sting in general. J Darou Darman 1990;8: 26-30 [in Persian].

13. Alkahlout BH, Abid MM, Kasim MM, Haneef SM. Epidemiological review of scorpion stings in Qatar. The need for regional management guidelines in emergency departments. Saudi Med J. 2015;36(7): 851-5.

14. Shahi M, Rafinejad J, Az-Khosravi L, Moosavy SH. First report of death due to Hemiscorpius acanthocercus envenomation in Iran: Case report. Electron Physician. 2015;7(5): 1234-8.

15. Radmanesh M. Clinical study of Mesobuthus eupeus stinging. J Darou Darman. 1990;7: 40-2 [in Persian].

16. Radmanesh M, Shaffiee S. Clinical study of Apistobuthus pterygocercus sting. J Daru Darman. 1989;6(63): 9-10 [in Persian].

17. Razi E, Malekanrad E. Asymmetric pulmonary edema after scorpion sting: a case report. Rev Inst Med trop S Paulo. 2008;50(6): 34750 .

18. Dehghani R, Djadid ND, Shahbazzadeh D, Bigdelli S. Introducing Compsobuthus matthiesseni (Birula, 1905) scorpion as one of the major stinging scorpions in Khuzestan, Iran. Toxicon. 2009;54(3): 2725.

19. Aghabiklooei A, Zamani N, Hassanian-Moghaddam H. Getting stung by black scorpion Androctonus crassicauda: a case report. Hum Exp Toxicol. 2014;33(10): 1081-4.

20. Radmanesh M. Androctonus crassicauda sting and its clinical study in Iran. J Trop Med Hyg. 1990;93(5): 323-6.

21. Dehghani R, Khamechian T. Scrotum injury by scorpion sting. Iranian J Arthropod Borne Dis. 2008;2(1): 49-52.

22. Zare Mirakabadi, A. Hemiscorpius lepturus envenomation: Manifestations and management with specific antivenom. Archiv Razi Inst. 2013;68(2): 91-9.

23. Radmanesh M. Cutaneous manifestations of the Hemiscorpius lepturus sting: a clinical study. Int J Dermatol. 1998;37(7): 500-7.

24. Emam SJ, Khosravi AD, Alemohammad A. Evaluation of hematological and urine parameters in Hemiscorpius lepturus (Gadim) victims referred to Razi Hospital, Ahwaz, Iran. J Med Sci. 2008;8(3): $306-9$

25. Emam SJ, Malihi R, Jafari Mosavi SA, Vazirianzadeh B, Visi I. Evaluation of hematological and urine parameters in Hemiscorpius lepturus (Gadim) victims referred to health centre of Hendijan, sw Iran. Jundishapur J Health Sci. 2011;3(1): 12-8 [in Persian].

26. Jalali A, Pipelzadeh MH, Sayedian R, Rowan EG. A review of epidemiological, clinical and in vitro physiological studies of envenomation by the scorpion Hemiscorpius lepturus (Hemiscorpiidae) in Iran. Toxicon. 2010;55(2-3): 173-9.

27. Pipelzadeh MH, Jalali A, Taraz M, Pourabbas R, Zaremirakabadi A. An epidemiological and a clinical study on scorpionism by the Iranian scorpion Hemiscorpius lepturus. Toxicon. 2007;50: 984-92.

28. Rahmani AH, Jalali A. Symptom patterns in adult patients stung by scorpions with emphasis on coagulopathy and hemoglobinuria. J Venom Anim Toxins incl Trop Dis. 2012;18(4): 427-31.

29. Afzali N, Pezeshki N. The study of acute renal failure due to Hemiscorpius lepturus sting in children. Sci Med J Ahwaz Uni Med Sci. 1999;25: 42-8 [in Persian].

30. Radmanesh M. Clinical study of Hemiscorpius lepturus in Iran. J Trop Med Hyg. 1990;93(5): 327-32.

31. Sadeghian H. Transient ophthalmoplegia following envenomation by the scorpion

Mesobuthus eupeus. Neurology. 2003;60(2): 346-7.

32. Shayesteh AA, Zamiri N, Peymani P, Jassemi Zargani F, Lankarani $\mathrm{KB}$. A novel management method for disseminated intravascular coagulation like syndrome after a sting of Hemiscorpius lepturus: A case series. Trop Biomed. 2011;28(3): 518-23.

33. Valavi E, Alemzadeh Ansari M J. Hemolytic uremic syndrome following Hemiscorpius lepturus (scorpion) sting. Indian J Nephrol. 2008;18(4): 166-8.

34. Rafizadeh S, Rafinejad J, Rassi Y. Epidemiology of Scorpionism in Iran during 2009. J Arthropod-Borne Dis. 2013;7(1): 66-70.

35. Dehghani R, Rafinejad J, Fathi B, Panjeh Shahi M, Jazayeri M, Hashemi A. A Retrospective Study on Scropionism in Iran (20022011). J Arthropod-Borne Dis. 2016; May [Epub ahead of print]

36. Labaf Ghasemi R. Status of scorpion sting in Iran and its control Behvarz J. 1999;10(2): 32-5 [in Persian].

37. Paknahad A, Pouraskar M, Ghasemi Pour A. A review of scorpion stings in Iran. J Curr Res Sci. 2014;2(6): 887-90.
38. Radmanesh M. Study of Scorpion sting in Province of Khuzestan. J Darou Darman. 1987;38: 12-9 [in Persian].

39. Vazirianzadeh B, Farhadpour F, Hosseinzadeh M, Zarean M, Moravvej SA. An Epidemiological and Clinical Study on Scorpionism in Hospitalized Children in Khuzestan, Iranian J Arthropod-Borne Dis. 2012:6(1): 62-9.

40. Shahbazzadeh D, Amirkhani A, Djadid ND, Bigdeli S, Akbari A, Ahari H, Amini H, Dehghani R. Epidemiological and clinical survey of scorpionism in Khuzestan province, Iran (2003). Toxicon. 2009;53(4): 454-9.

41. Chitnis PA, Maraghi S, Vazirianzadeh B. Epidemiological and laboratory study on scorpion stings in Khuzestan province. J Guilan Univ Med Sci. 1993;2(8): 5-12 [in Persian].

42. Ghaderi H. Evaluation of scorpion bites in the military soldiers in north-western part of Khuzestan province from May 2002 to December 2003. Ann Mil Health Sci Res. 2004;2(4): 451-5 [in Persian].

43.Ghaderi H, Shariati Z, Ghodoosi AR, Ziyaee M. Scorpion bites in the north-western of Khuzestan province from May 2002 to December 2003. Hayat. 2006;12(2): 73-8 [in Persian].

44. Maghsoodi N, Vazirianzadeh B, Salahshoor A. Scorpion Sting in Izeh, Iran: An Epidemiological Study During 2009. 2011. J Basic Appl Sci. 2015;11: 403-9.

45. Mohseni A, Vazirianzadeh B, Hossienzadeh M, Salehcheh M, Moradi A, Moravvej SA. The roles of some scorpions, Hemiscorpius lepturus and Androctonus crassicauda, in a scorpionism focus in Ramhormorz, southwestern Iran. J Insect Sci. 2013;13:89.

46. Karami Kh, Vazirianzadeh B, Mashhadi E, Hossienzadeh M, Moravvej SA. A Five Year Epidemiologic Study on Scorpion Stings in Ramhormoz, South-West of Iran. Pak J Zool. 2013;45(2): 469-74.

47. Kassiri H, Teimouri A, Shemshad M, Sharifinia N, Shemshad K. Epidemiological Survey and Clinical Presentation on Scorpionism in South-West of Iran. Middle East J Sci Res. 2012;12(3): 325-30.

48. Kassirei H, Kassiri E, Veyz-Behbahani R, Kassiri A. Epidemiological survey on scorpionism in Gotvand County, Southwestern Iran: an analysis of 1067 patients. J Acute Dis. 2014;3(4): 314-9.

49. Isazadehfar KH, Eslami L, Entezariasl M. Epidemiology of Scorpionism in southwest, Iran, 2008. Iran J Epidemiol. 2013;8(4): 54-60 [in Persian].

50. Rahmani AH, Forouzandeh H, Kalantar M, Asad-Masjedi N, Alavian Z, Kavarizadeh K. Epidemiological and Clinical Characteristics of Scorpion Stings in Ahwaz, Southwest Iran (2006-2010). IJMTFM. 2015;5(4): 201-6.

51. Vazirianzadeh B, Haji Hossein R, Amri B, Bageri S, Molaei SM. Epidemiological study of scorpionism in the hospitals of Ahvaz, sw Iran, 2nd six months of 2006. Jundishapur J Health Sci. 2010;2(1): 16-25 [in Persian]

52. Mashak Z, Nemat R, Mahboobian B. Epidemiologic survey of scorpion sting in Abozar hospital, Ahwaz province, Iran between 19891990. Hakim. 2000;3(3): 215-23 [in Persian].

53. Mir Dehghan MM, Motlagh ME, Chomeili B. A 5-year study of scorpion stings in children referred to Abuzar Paediatric Centre in Ahvaz, 1994-99. Urmia Med J. 2001;2: 138-46 [ in Persian].

54. Kassiri H, Shemshad K, Kassiri A, Shemshad M, Valipor AA, Teimori A. Epidemiological and Climatological Factors Influencing on Scorpion Envenoming in Baghmalek County, Iran. Acad J Entomol. 2013;6(2): 47-54.

55. Zamani-Alavijeh F, Dehdari T, Ahmadi Angali K, Taghi Rahdari M, Azar Abdar T, Ashrafi Hafez A, Babaei Heydarabadi A. Investigation of Temporal Pattern of Scorpion Sting and Snakebite Incidence in Patients Referred to Masjedsoleiman's Main Hospital, During 24 Months from 21 March 2008 to 20 March 2009. J Safe Promot Inj Prev. 2014;1(4): 190-7 [in Persian].

56. Vazirianzadeh B, Hossienzadeh M, Moravvej SA, Vazirianzadeh M, Mosavi SA. An Epidemiological Study on Scorpion Stings in Lordegan County, south-west of Iran. Arch Razi Inst. 2013;68(1): 71-6.

57. Molaee SM, Angali Ahmadi K, Vazirianzadeh B, Moravvej SA. A Climatological Study of Scorpion Sting Incidence From 2007 to 2011 in the Dezful Area of Southwestern Iran, Using a Time Series Model. J Insect Sci. 2014;14(151): 1-6.

58. Kassiri H, Mohammadzadeh Mahijan N, Hasanvand Z, Shemshad M, Shemshad Kh. Epidemiological Survey on Scorpion Sting Envenomation in South-West, Iran. Zahedan J Res Med Sci. 2012;14(8): 80-3.

59. Manouchehrifar M, Khosravi S, Khavanin A, Derakhshandeh N. Report of 267 Cases 
of Scorpion Bite Referring to an Emergency Department during One Year. Emerg

(Tehran). 2013;1(1): 24-6.

60. Kassiri H, Kasiri A, Kasiri E, Safarpor S, Lotfi M. A Hospital-based Study on Scorpionism in Khorram-Shahr County, Southwestern Iran. Asian J Epidemiol. 2014;7(2): 28-35.

61. Kassiri H, Feizhaddad MH, Abdehpanah M. Morbidity, surveillance and epidemiology of scorpion sting, cutaneous leishmaniasis and pediculosis capitis in Bandar-Mahshahr County, Southwestern Iran. J Acute Dis. 2014;3(3): 194-200.

62. Kassiri H, Kasiri A, Kasiri E, Abdian P, Matori F, Lotfi M. Epidemiological characteristics and incidence rate of definite scorpion stings in Mahshahr County, Iran: multivariate analysis of 1635 cases. Asian Pac J Trop Dis. 2015;5(1): 80-4.

63. Taj Sh, Vazirian M, Vazirianzadeh B, Bigdeli Sh, Salehzadeh Z Effects of climatological variables on scorpion sting incidence in Ramshir area south west of Iran. J Exp Zool India. 2012;15(2): 575-7.

64. Pourrezai S, Hossieni A, Vazirianzadeh B, Gardani HA, Salehzadeh Z. Study on some epidemiological parameters among scorpion stung people treated at Ramshir Health Centre, south west Iran. J Exp Zool India. 2015;18(1): 345-8

65. Gholizadeh S, Lalehzari E, Mohammadi Bavani M, Hosseini A, Khalkhali HR, Rafinejad J. Bioecology and scorpion envenomation in Ramshir district, Khuzestan Province, southwestern Iran. Appl Entomol Zool. 2016;51(1): 37-42.

66. Moosavy SH, Shahi M, Rafinejad J, Zare S, Madani A, Navidpour S. Epidemiological aspect of scorpion sting in Bandar Abbas, Iran, during 2009-2011. Electron Physician. 2016;8(4): 2286-90.

67. Safdarian F. Scorpion bites in hospital admitted children in Bandar Abbass. Hormozgan Med J. 2001;5(2): 26-30 [in Persian].

68. Shahi M, Moosavy SH, Rafinejad J, Zare S, Navidpour S, Madani A. Epidemiological and Clinical Aspects of Scorpion Sting among Children in South Part of Iran. Glob J Health Sci. 2017;9(3): 289-95.

69. Dehghankhalili M, Mobaraki H, Akbarzadeh A, Yazdani R, Nazemi A, Ghaffarpasand F, Mohammadi Z, Shahrzad ME, Mohmudi F, Taghavi M, Dehghankhalili S. Clinical and

Laboratory Characteristics of Pediatric Scorpion Stings: A Report from Southern Iran. Pediatr Emerg Care. 2015; Nov 2. [Epub ahead of print]

70. Shahi M, Moosavy SH, Hanafi-Bojd AA, Navidpour S, Zare S, Madani A, Rafinejad J. Spatial Distribution of Scorpion Sting in a High-Risk Area of Southern Iran. J Med Entomol. 2016 [Epub ahead of print].

71. Talebian A, Doroodgar A. Epidemiologic study of scorpion sting in patients referring to Kashan medical centers during 1991-2002. Iran J Clinic Infect Dis. 2006;1(4): 191-4.

72. Dehghani R, Doroudgar A, Khademi MR, Sayyah M. The survey of scorpion sting in the city of Kashan. J Res Med Sci. 1998;2(3): 132-5 [in Persian].

73. Dehghani R, Droudgar A, Khademi M, Sayyah M. A survey of scorpion stings in central Iran. Res Med Sci J (Pajoohesh dar Olum-ePezehski). 1998;3(2): 132-5. [in Persian]

74. Dehghani R, Vazirianzadeh B, Nasrabadi MR, Moravvej SA. Study of scorpionism in Kashan in central Iran. Pak J Med Sci. 2010;26(4): 955-8

75. Nazari M, Bahrami D, Davari B, Salehzadeh A. Epidemiological Survey of Scorpion Sting Cases and Identification of Scorpion Fauna in Hamadan City, Iran (2013). Sci J Hamadan Univ Med Sci. 2015;22(3): 255-62 [in Persian].

76. Khatony A, Abdi A, Fatahpour T, Towhidi F. The epidemiology of scorpion stings in tropical areas of Kermanshah province, Iran, during 2008 and 2009. J Venom Anim Toxins incl Trop Dis. 2015;21: 45

77. Prevalence of Scorpion sting in tropical areas of Kermanshah province during 2009-2010. J Clin Res in Paramed Sci. 2013;2(2): 77-89 [in Persian].

78. Daneshi S, Rezabeigi S, Razzaghi A, Zeinali M, Arefi S. The epidemiological analysis of scorpion stings in Kerman. 2012-14. Pejouhandeh. 2016;21(1): 35-39 [in Persian].

79. Hosseininasab A, Alidousti Shahraki K, Torabinezhad MH. Epidemiologic characteristic and predisposing factors of scorpion sting in the south of Kerman province. J Med Counc I R Iran. 2009;27(3): 295-301 [in Persian].

80. Vazirianzadeh B, Nourmandi Pour S, Hashemi Shahraki A, Dehghani R, Amraee K. Letters to the editor: A study on some epidemiologic parameters among scorpion stung people who referred to
Sirjan Health Centre, Kerman province of Iran in 2007-2009. Jentashapir J Health Res (Jentashapir). 2013;3(4): 539-43.

81. Nazari M, Hajizadeh M. A Faunistic Study on Scorpions and the Epidemiology of Scorpionism in Bam, Southeast of Iran. Global J Health Sci. 2017;9(2): 177-83.

82. Kassiri H, Kassiri N, Dianat A. Species composition, sex ratio, geographical distribution, seasonal and monthly activity of scorpions and epidemiological features of scorpionism in Zarrin-dasht County, Fars Province, Southern Iran. Asian Pac J Trop Dis. 2015;5(Suppl 1): S99S103.

83. Nejati J, Mozafari E, Saghafipour A, Kiyani M. Scorpion fauna and epidemiological aspects of scorpionism in southeastern Iran. Asian Pac J Trop Biomed. 2014;4(Suppl 1): S217-S221.

84. Gheshlaghi F, Yaraghi A, Hashemi ES. An Epidemiological Study on Scorpionism in Isfahan Province. J Isfahan Med Sch. 2011;28(114): 1-7 [in Persian].

85. Saghafipour A, Noroozi M, Karami Jooshin M. The Epidemiologic Status of Scorpion Stings in Qom Province, 2001-2011. J Safe Promot Inj Prev. 2013;1(2): 95-101 [in Persian].

86. Vatani H, Khoobdel M. Scorpion fauna in Taybad region and scorpion sting status in military environment. J Mil Med. 2009;1(11): 7 11 [in Persian].

87. Shams Vahdati S, Moradi N. Scorpion Bite in North West Iran. Tr J Emerg Med. 2012;12(4): 149.

88. Shahsavarinia K, Taghizadieh A, Ghaffarzad A, Shariati A, Rahmani F. Epidemiological and clinical status of patients with scorpion sting: emergency department of Sina hospital in Tabriz-Iran. Journal of Emergency Practice and Trauma. 2017; 3(1): 18-21.

89. Mogaddam MY, Dehghani R, Enayati AA, Fazeli-Dinan M, Motevalli Haghi F. Epidemiology of Scorpionism in Darmian, Iran, 2015 J Mazandaran Univ Med Sci. 2016;26(141): 131-6 [in Persian].

90. Sagheb MM, Sharifian M, Moini M, Sharifian AH. Scorpion bite prevalence and complications: report from a referral centre in southern Iran. Trop Doct. 2012;42(2): 90-1.

91. City Population, http://www.citypopulation.de/php/iran-fars.php

92. Farzanpay R. Scorpionology. $1^{\text {st }}$ ed. Tehran, Iran: Markaz Nashr Daneshgahi; 1987 [in Persian].

93. Dehghani R, Valaie N. Classification of scorpions and their Diagnostic Clue. FEYZ, J Kashan Univ of Med Sci. 2005;8(4): 73-92 [in Persian]

94. Navidpour S. A review study on Hottentotta Birula, 1908, (Scorpionida: Buthidae) species collected from Iran. Arch Razi Inst. 2012;67(2): 93-100

95. Azizi K, Tirgary S, Sayedi-Rashti MA. Faunestic Study of Scorpions in Shiraz and Investigation on their Fecundity. J Armaghan Danesh. 1998;3(9,10): 23-32 [in Persian].

96. Ebrahimi M, Azizi K, Moemenbellah-Fard MD, Fakoorziba MR Soltani A. Morphometry Indices of the Black Fat-tailed Scorpion Androctonus crassicauda (Scorpiones Buthidae), from Fars Province, Southern Iran. J Entomol. 2015;12(1): 39-47.

97. Ozkan O, Kat I. Mesobuthus eupeus scorpionism in Sanliurfa region of Turkey. J Venom Anim Toxins incl Trop Dis. 2005;11(4): 479-91.

98. Zargan J, Tirgari S, Tahernejad K, Lotfi H, Farahmandzad A. Study of scorpion fauna in Abomosa, Great \& Small Tonbs and Hengam Islands of the Persian Gulf. Iran South Med J. 2003;6(1): 20-4 [in Persian].

99. Khaghani R, Tirgari S, Omrani G, Rafinejad J, Moosavi Ivanaki A Faunestic study and biodiversity of scorpions in Kish Island, Iran (Persian Gulf). Modares J Med Sci. 8(1): 7-11 [in Persian].

100. Shahi M, Azizi K, Ansarian N. Study on Scorpions fauna in high risk area of Hormozgan province, 2006-7. Hormozgan Med J. 2009;12(4): 207-14 [in Persian].

101. Zarei A, Rafinejad J, Shemshad K, Khaghani R. Faunistic Study and Biodiversity of Scorpions in Qeshm Island (Persian Gulf). Iran J Arthropod-Borne Dis. 2009;3(1): 46-52.

102. Akbari A, Tabatabei SM, Hedayat A, Modir Roosta H, Alizadeh MH, Kamalzare M. A study of the geographical distribution of the scorpions in the south of Iran. Pajouhesh va Sazandegi. 1997:34 112-5 [in Persian]

103. Habibi T. Liste de scorpion de l'Iran. Bulletin of the Faculty of Science, Tehran University. 1971;2(4): 42-7.

104. Dehghani R. Scorpions and Scorpion Sting (Biology, Ecology and Control of Them). Publications of Kashan University of Medical Sciences; Esfahan Beautiful Arts, Esfahan, 2006; 334 [in Persian]. 
105. Navidpour S. Fet V, Kovařík F, Soleglad ME. Scorpions of Iran (Arachnida, Scorpiones).

Part VIII. Fars Province. Euscorpius. 2012;139: 1-29

106. Kovaŕík F. A revision of the genus Hottentotta Birula, 1908, with descriptions of four new species (Scorpiones, Buthidae). Euscorpius. 2007;58: 1-107.

107. Navidpour S. Kovařík F, Soleglad ME, Fet V. Scorpions of Iran (Arachnida, Scorpiones). Part I. Khoozestan Province. Euscorpius. 2008;65: 1-41.

108. Navidpour S, Nayebzadeh HH, Soleglad ME, Fet V, Kovařík F, Kayedi MH. Scorpions of Iran (Arachnida, Scorpiones). Part VI. Lorestan Province. Euscorpius. 2010;99: 1-23.

109. Karataş A, Garkheloo MM, Uçak M. Contribution to the distribution of the scorpions of Iran. Zool Middle East. 2012;55: 111-20.

110. Pirali-Kheirabadi K, Navidpour S, Fet V, Kovařík F, Soleglad ME. Scorpions of Iran (Arachnida, Scorpiones). Part V. Chahar Mahal \& Bakhtiyari Province. Euscorpius. 2009;78: 1-23.

111. Pirali-Kheirabadi K, Khalaji-Pirbalouty V, Jazayeri A. Geographical distribution of scorpions in Chaharmahal va Bakhteyari Province. Veterinary Journal (Pajouhesh \& Sazandegi). 2014;103: 44-51 [in Persian]

112. Navidpour S. Kovařík F, Soleglad ME, Fet V. Scorpions of Iran (Arachnida, Scorpiones). Part IV. Kohgilouyeh \& Boyer Ahmad Province. Euscorpius. 2008;74: 1-24.

113. Sanaei-Zadeh H. Hypersensitivity reaction to scorpion antivenom. Indian Dermatol Online J. 2014;5(Suppl 1): S51-2.

114. Valavi E. Step by Step Treatment of Scorpion Sting in South West of Iran. Jundishapur Sci Med J. 2016;15(1): 117-24 [in Persian]. 